Sains Malaysiana 48(6)(2019): 1201-1207

http://dx.doi.org/10.17576/jsm-2019-4806-07

\title{
Characterization of Graphene based Capacitive Microphone
}

(Pencirian Grafen berasaskan Mikrofon Sentuh Berkapasitor)

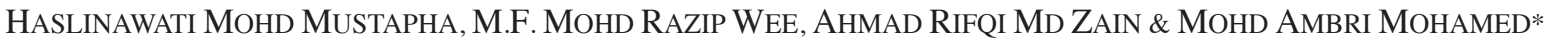

\section{ABSTRACT}

This research focuses on the design, fabrication and characterization of the graphene based capacitive microphone. Finite element analysis (FEA) is first simulated in order to design and study the proposed graphene based capacitive microphone. While the fabrication introduced MEMS technique in order to reduce the physical size, volume and cost without neglecting the performance. This study discusses on physical characteristics of graphene diaphragm for capacitive microphone. The fabrication of $200 \mathrm{~nm}$ air gap and the free-standing suspended graphene with the contribution of the van der Waals force between the graphene layer as a diaphragm and the substrate are presented in this study. The first stage involved in this study was the photolithography process of patterning electrodes with 4 different dimensions of diaphragm. The characterization was performed by using surface profilometer, optical microscopy, Raman spectroscopy and FESEM to evaluate the physical characteristics of the diaphragm. In the last stage, LCR meter was used to measure the capacitive change with different diameter of graphene diaphragm within frequency range of $20 \mathrm{~Hz}$ to $20 \mathrm{kHz}$. FEA analysis showed the good sensitivity against the frequency response for the largest proposed diameter of diaphragm.

Keywords: Capacitive microphone; frequency range; graphene diaphragm; MEMS

\section{ABSTRAK}

Kajian ini memberi tumpuan kepada reka bentuk, fabrikasi dan pencirian mikrofon kapasitif berasaskan grafen. Pada permulaan, FEA disimulasikan untuk mereka bentuk dan mengkaji mikrofon kapasitif berasaskan grafen. Manakala fabrikasi ini memperkenalkan teknik MEMS untuk mengurangkan ukuran fizikal, isi padu dan kos tanpa mengabaikan prestasi. Kajian ini membincangkan ciri fizikal diafragma grafen untuk mikrofon kapasitif. Kami membentangkan fabrikasi lubang udara sebanyak $200 \mathrm{~nm}$ dan grafen tergantung bebas dengan sumbangan kekuatan daya Van Der Waals antara lapisan grafen sebagai diafragma dan substrat. Tahap pertama akan melibatkan proses fotolitografi elektrod dengan 4 dimensi berlainan diameter diafragma. Penciriannya dilakukan oleh permukaan profilometer, mikroskop optik, spektroskopi Raman dan FESEM untuk menilai ciri-ciri diafragma. Di peringkat terakhir, meter LCR digunakan untuk mengukur perubahan kapasitif dengan diameter diafragma grafen yang berbeza dengan julat frekuensi $20 \mathrm{~Hz}$ hingga 20 kHz. Analisis FEA menunjukkan sensitiviti yang baik terhadap tindak balas frekuensi bagi diameter yang paling besar.

Kata kunci: Grafen diafragma; julat frekuensi; kapasitif mikrofon; MEMS

\section{INTRODUCTION}

MEMS microphone has appeared more frequently in many researches nowadays. It is widely used in mobile phones and hearing aids. There are two types of microphone: Capacitive and dynamic microphone. Both are different in terms of ways and operational function. Capacitive microphone contains diaphragm, air gap, cavity, back plate holes and vent channel. Diaphragm vibrates and acts as a capacitor plate. The first capacitive microphone was developed by E.C. Wente. Capacitive microphone can achieve higher sensitivity with a low noise level compared to other type of microphone (Wang et al. 2004).

Material selection to be utilized as a diaphragm also needs to be studied and with rapid development in world of research, it is not impossible to discover a new material that can compete with the existing materials. The existing microphone uses a silicone based (Alfons 2007) or polymer based (Pedersen et al. 1997) suspended diaphragm. However, these two materials need a larger diameter of diaphragm in order to accommodate with the thickness of the material to provide suitable dimension for the device. Microfabrication technique in Micro-ElectroMechanical Systems or MEMS is a technology that in its most general suits to breakthroughs the future. In fact, the cost can be reduced since graphene can be produced by many ways including mechanical exfoliation as discovered in 2004 (Geim \& Novoselov 2007), epitaxial growth on $\mathrm{SiC}$ (Huang et al. 2014), and chemical vapor deposition CVD technique (Edhuan et al. 2017). CVD method becomes a promising method to produce a large scale of graphene with good quality (Hafzaliza et al. 2017).

Recently, there are many uses of graphene in pressure and acoustic sensor (Wang et al. 2015; Zhou \& Zettl 2013; Zhou et al. 2015). The discovery in 2015 proved that a 60 -layer graphene on Nickel foil increased the sensitivity of the device at $15 \mathrm{~dB}$ higher than commercial microphone 
(Todorovic et al. 2015). Recently, Beger et al. (2017) in his research affirmed that the single layer graphene can achieve good pressure sensitivity with the air gap less than $50 \mathrm{~nm}$. The researches of the current study fabricated, characterized and tested graphene as a diaphragm in MEMS capacitive microphone. The light, thin, flexible, high thermal conductivity, and high carrier mobility properties of graphene (Sajibul et al. 2016) make it as the right material in performing as an acoustic sensor.

\section{MATERIALS AND METHODS}

\section{FINITE ELEMENT ANALYSIS (FEA) OF MICROPHONE}

MEMS capacitive microphone was simulated using COMSOL Multiphysics version 5.3a software. The simulation discussed on the mechanical and acoustical effect of MEMS capacitive microphone using graphene as a diaphragm. First step is involved the theoretical modeling of the diaphragm which consist of the size diameter of diaphragm and secondly with the boundary element whereas the air gap distance was considered. We designed a circle diaphragm with different value of diameter, $15 \mu \mathrm{m}, 25 \mu \mathrm{m}$, $35 \mu \mathrm{m}$ and $40 \mu \mathrm{m}$. Below is the table of parameter value for the finite element analysis for this study.

TABLE 1. Input parameter value used in the model

\begin{tabular}{cc}
\hline Parameter & Value \\
\hline Diameter diaphragm & $15 \mu \mathrm{m}, 25 \mu \mathrm{m}, 35 \mu \mathrm{m}$ and $40 \mu \mathrm{m}$ \\
Diaphragm thickness & $500.33 \mathrm{~nm}$ \\
Air gap & $200 \mathrm{~nm}$ \\
Bias voltage & $3 \mathrm{~V}$ \\
\hline
\end{tabular}

\section{FABRICATIONS}

A basic capacitive microphone utilizes a parallel plate structure separated with air gap with a movable plate part known as diaphragm and a static part consisting of the $\mathrm{Si}$ wafer. The fabrication process involved the use of $\mathrm{Si}_{3} \mathrm{~N}_{4}$ as a substrate. First, the substrate underwent a cleaning process. It is a critical process in semiconductor and MEMS fabrication to eliminate the chemical or impurities without damaging the surface of the substrate. The sample was coated with AZ1500 before the patterning process by using spin coater at $4000 \mathrm{rpm}$. Photolithography process was used to pattern the design of the device with the desired dimension. The device underwent deep reactive ion etching process to create air gap through the holes. The process took $30 \mathrm{~s}$ to a depth of $200 \mathrm{~nm}$ as confirmed by the profilometer measurement. This process was operated at room temperature. Then, chromium and gold were deposited subsequently as the back electrodes using electron beam evaporation technique. After that, single layer graphene was transferred onto the device as a diaphragm. It was crucial to transfer the graphene carefully onto the right and desired location of diaphragm. The schematic diagram of the fabricated MEMS capacitive microphone is shown in Figure 1.

\section{CHARACTERIZATIONS}

Two types of characterization were further engaged in this study. The first characterization involved a physical properties measurement. Surface profilometer, optical microscopy, Raman spectroscopy and FESEM measurement were applied to ensure the presence and the structure of the graphene diaphragm. The second characterization

(a)

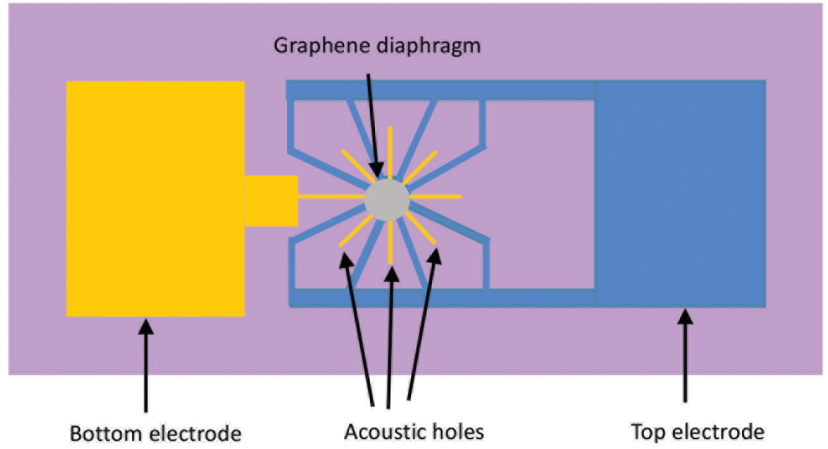

(b)

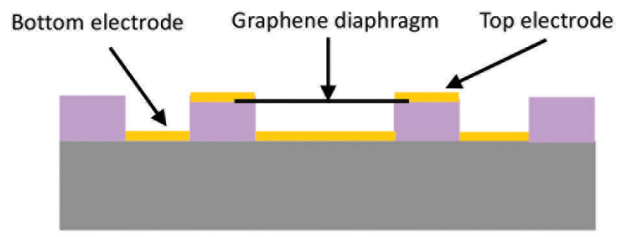

FIGURE 1. Schematic structure of the fabricated MEMS capacitive microphone (a) Top view (b) Side view 
elaborated on the electrical measurement of the device. The fabricated device was tested by using probe station to get the I-V characteristics. The LCR meter was used to measure the capacitance of each device in varied frequency ranging from $20 \mathrm{~Hz}$ to $20 \mathrm{kHz}$ with the bias voltage of $3 \mathrm{~V}$.

\section{RESULTS AND DISCUSSION}

\section{SIMULATION AND ANALYSIS}

The eigenvalue analysis is first simulated to study the value of resonant frequency of each proposed diameter of graphene diaphragm. As for results of sensitivity, frequency response and capacitance value are highly depending on the value of bias voltage. In this study, we reported the results from a bias voltage of $3 \mathrm{~V}$. The value of bias voltage must not exceed the value of pull-in voltage. Therefore, the variation of bias voltage is applied in order to optimize the value of pull-in voltage. Table 2 shows the output results of resonant frequency and pull-in voltage in this study.

TABLE 2. Resonant frequency, $f_{o}$ and pull in voltage $\mathrm{V}_{\mathrm{p}}$ with different diameter of diaphragm

\begin{tabular}{ccc}
\hline $\begin{array}{c}\text { Diameter } \\
\text { diaphragm }(\mu \mathrm{m})\end{array}$ & $\begin{array}{c}\text { Resonant frequency, } \\
f_{o}(\mathrm{MHz})\end{array}$ & $\begin{array}{c}\text { Pull-in voltage, } \\
\mathrm{V}_{\mathrm{p}}(\mathrm{V})\end{array}$ \\
\hline 15 & 2.18 & 45.2 \\
25 & 0.78 & 34.7 \\
35 & 0.39 & 23.5 \\
40 & 0.30 & 14.6 \\
\hline
\end{tabular}

A uniform pressure $1 \mathrm{~Pa}$ was applied on the diaphragm to study on the displacement deflection of the diaphragm ( $\mathrm{Z}$ direction). The relation between the diaphragm deflection responses at $3 \mathrm{~V}$ bias for proposed diameter diaphragm is demonstrated in Figure 2.

Sweep stationary function was implemented to plot the results of capacitance against the range of bias voltage. This simulated study used range of the bias voltage from

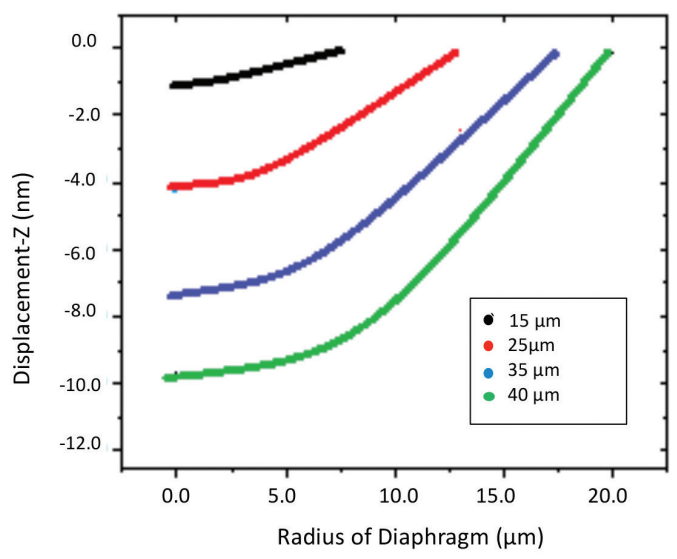

FIGURE 2. Graph of displacement-Z (nm) versus radius of diaphragm $(\mu \mathrm{m})$
$1.5 \mathrm{~V}$ to $10.5 \mathrm{~V}$. This range is taken because the bias voltage must not exceed the pull-in voltage $\left(\mathrm{V}_{\mathrm{p}}\right)$ to ensure the diaphragm is not sticking to the back plate. As the bias voltage was applied, the value of capacitance was changed. As in Figure 3, there is no interrupting or hysteresis in the plot. This $\mathrm{C}-\mathrm{V}$ curve is important in order to make certain that the proposed microphone is stable against the applied bias voltage.

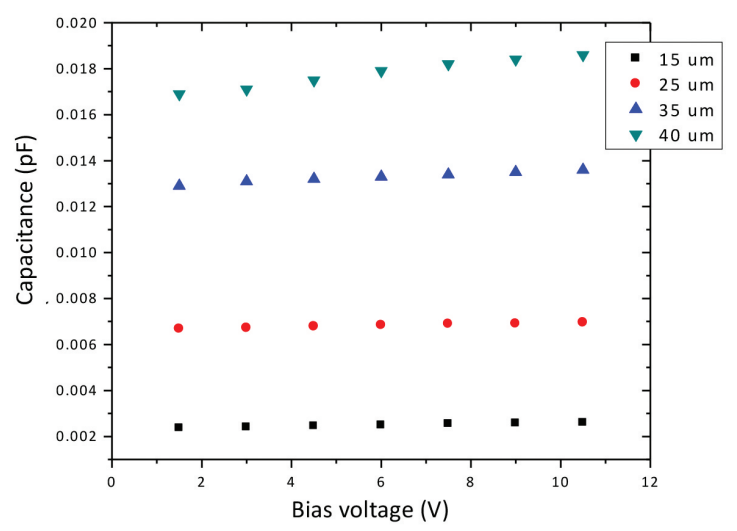

FIGURE 3. Graph of capacitance $(\mathrm{pF})$ versus bias voltage $(\mathrm{V})$ for different diameter diaphragm

\section{CAVITY OBSERVATION}

The fabrication process was started right after the simulated analysis was done. A series of physical characterizations of the device were identified to ensure the physical properties of the device. First, the depth of the acoustic holes was measured after deep reactive ion etching (DRIE) was carried out. The depth was measured by using surface profilometer. Figure 4 shows the image of the step height profile of the acoustic holes of the device. The results showed the depth of $200 \mathrm{~nm}$ after $30 \mathrm{~s}$ of the etching process with the presence of the sulfur hexafluoride gas $\left(\mathrm{SF}_{6}\right)$ at room temperature. The etching rate was found to be $6.67 \mathrm{~nm} / \mathrm{s}$. This step measurement was carried out in several different positions of acoustic holes to confirm the accuracy of the depth value over the whole cavity.

Optical microcopy image was taken to confirm the image before and after the etching process. Figure 5(a) shows the purple color of the patterned image which indicates the present of the Nitrite. After the etching process, the blue color of the patterned image was observed (Figure 5(b)). The change of color from purple to blue suggested that the layer of nitrite was perfectly etched away from the surface of the substrate during the etching process. Figure 6 shows the corresponding image under scanning electron microscope.

\section{GRAPHENE CHARACTERISTICS}

Raman spectroscopy is the most important tool in determining the graphene material. The existence of characteristics peaks of graphene, D, G and 2D can be determined by this technique. Therefore, Raman 

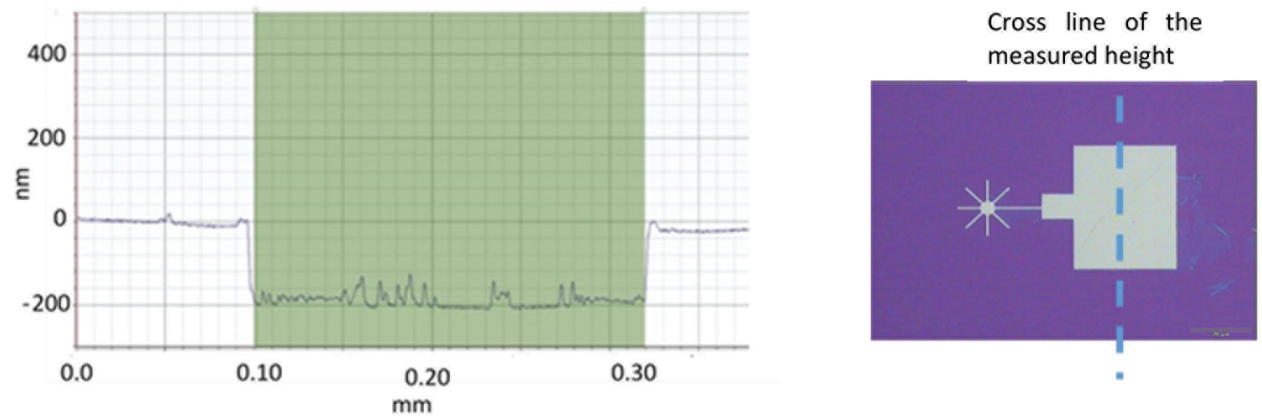

FIGURE 4. Image of step height measurement of acoustic holes by surface profilometer
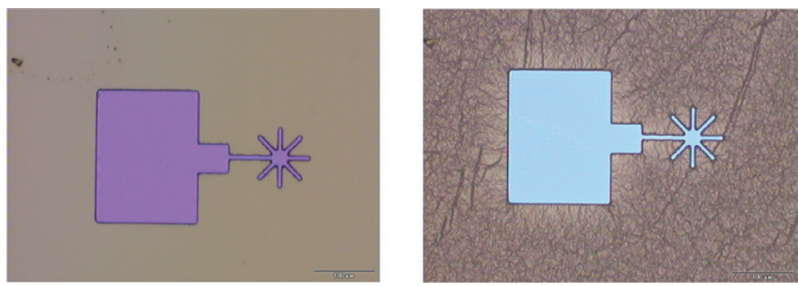

FIGURE 5. Optical microscopy image of the patterned device (a) before deep RIE process (b) after deep RIE process

spectroscopy was used in this study to characterize the graphene diaphragm of the device after the transferring process. Figure 7 shows the Raman spectrum of the graphene diaphragm with 4 different dimensions of diameter. A sharp and most intense peak of 2D was

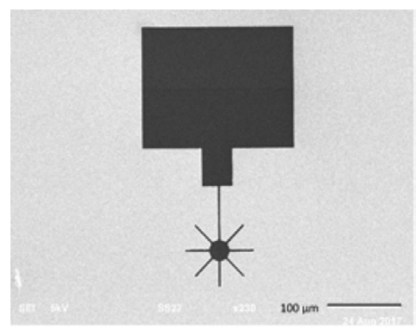

FIGURE 6. SEM image of patterned device observed at the range of $2600 \mathrm{~cm}^{-1}$ to $2800 \mathrm{~cm}^{-1}$ for all dimensions. A weak peak appeared within the range of $1350 \mathrm{~cm}^{-1}$ to $1450^{-1}$ and was identified as D peak that caused by disordered structure of graphene. The other peak, known as $\mathrm{G}$ peak that appeared in the range of $1550 \mathrm{~cm}^{-1}$
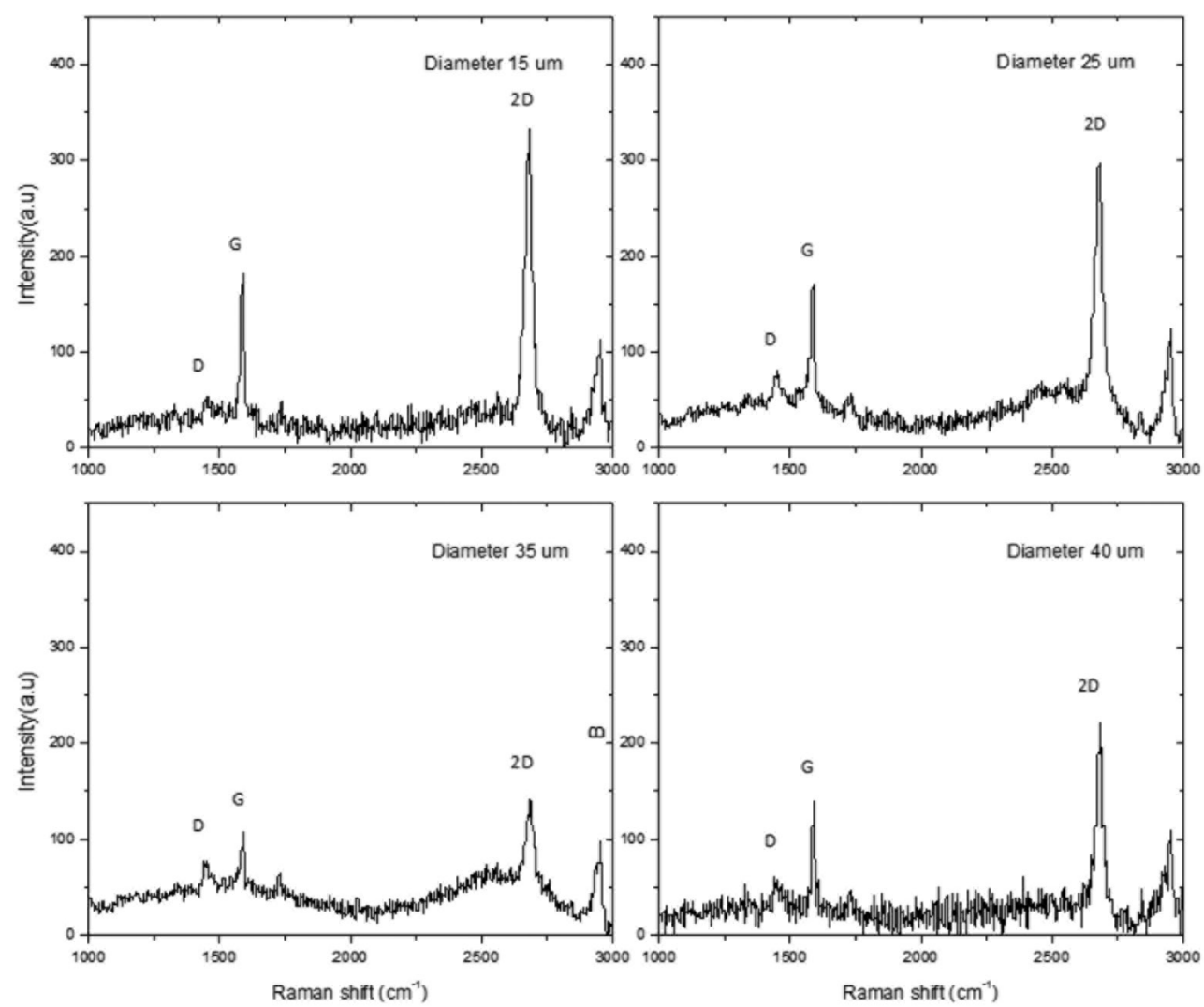

FIGURE 7. Raman spectrum of graphene diaphragm with different diameter (532 nm laser wavelength, $3.2 \mathrm{~mW}$ laser power) 
to $1700 \mathrm{~cm}^{-1}$ was referring to the stretching $\mathrm{C}-\mathrm{C}$ bond in the material. The defect or disordered structure of graphene is believed to occur during the transferring process. The surface structure of the graphene was further analyzed by FESEM.

Figure 8 shows the FESEM image of the graphene diaphragm with 300 and 500 magnifications. It was observed from the image that small pits existed as shown in Figure 8(a) were believed to contribute to a small defect in the graphene diaphragm. This was consistent with the Raman spectrum observed beforehand, where a weak D peak appeared in the spectrum.

\section{ELECTRICAL CHARACTERISTICS}

The fabricated devices with different dimension of diaphragm were then measured by probe station to get the I-V characteristics (Figure 9). This measurement was performed to assess the conductivity of the devices. The I-V characteristics showed the Ohmic behavior for all devices and the value of the conductivity was observed to be pretty much similar for all devices within the range of $0.2 \mathrm{nA}$. This characterization was performed to ensure that the graphene is in good condition without any tear after transferring process.

LCR meter was used to perform the capacitance measurement. The frequency range was set from $20 \mathrm{~Hz}$ to $20 \mathrm{kHz}$. The graph in Figure 10 shows that capacitance (y-axis) is inversely proportional to the frequency (x-axis) for all devices. This trend agreed with the equation of,

$$
C=\frac{1}{2 \pi f X_{C}}
$$

where $C$ is the capacitance $(\mathrm{F}) ; f=$ frequency $(\mathrm{Hz})$; and $X c$ is the capacitive reactance $(\Omega)$.
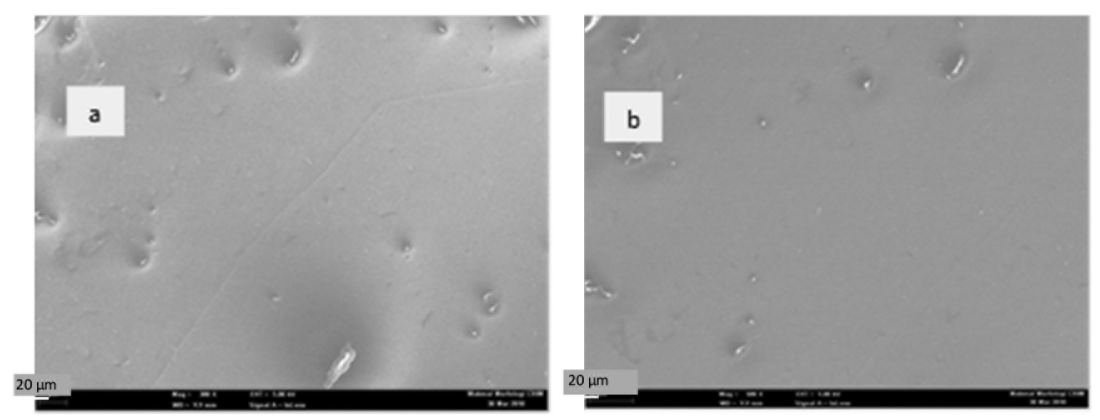

FIGURE 8. FESEM image of surface of graphene diaphragm with (a) 300 magnification (b) 500 magnification
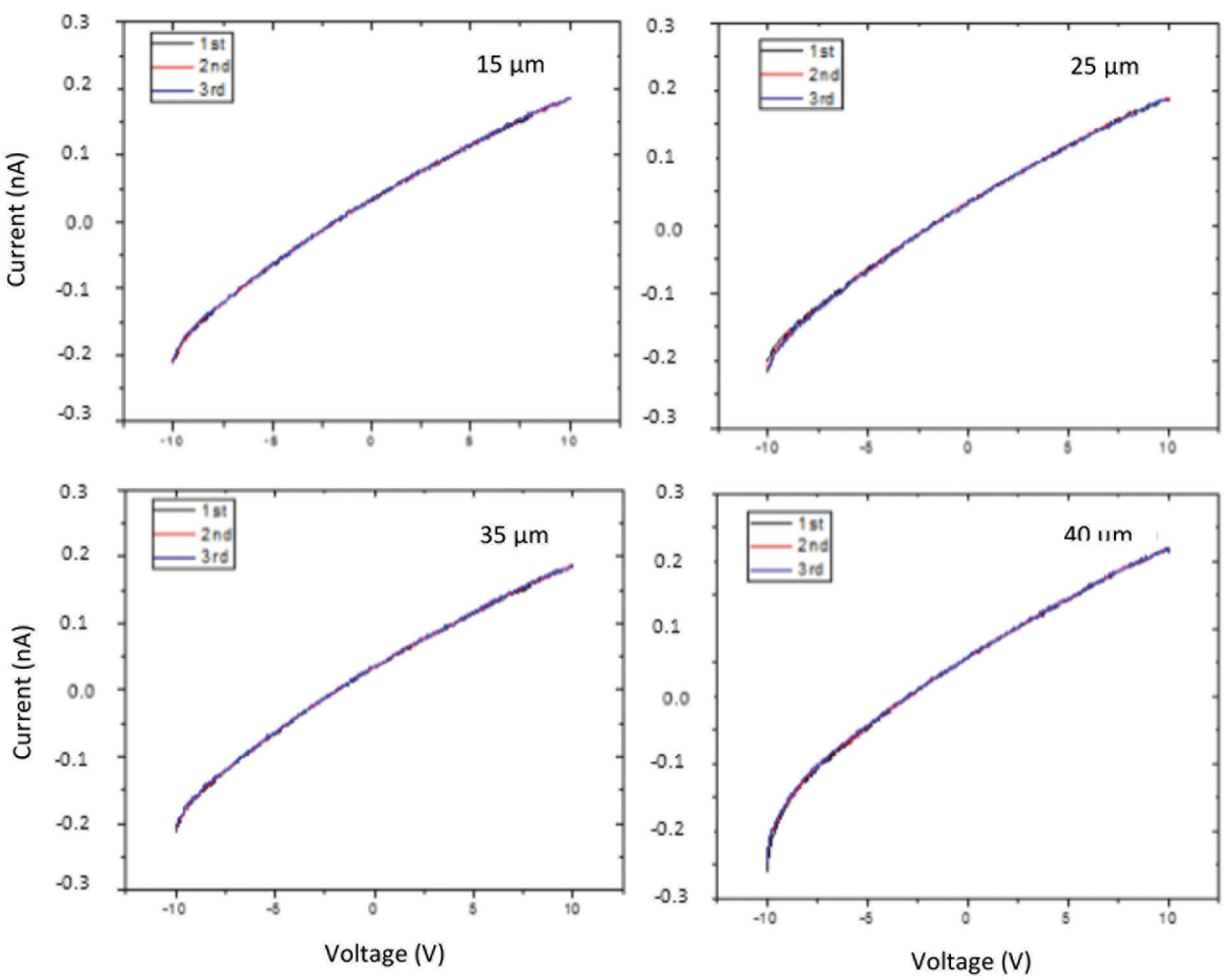

FIGURE 9. I-V characteristics of fabricated devices with different diameter of diaphragm 

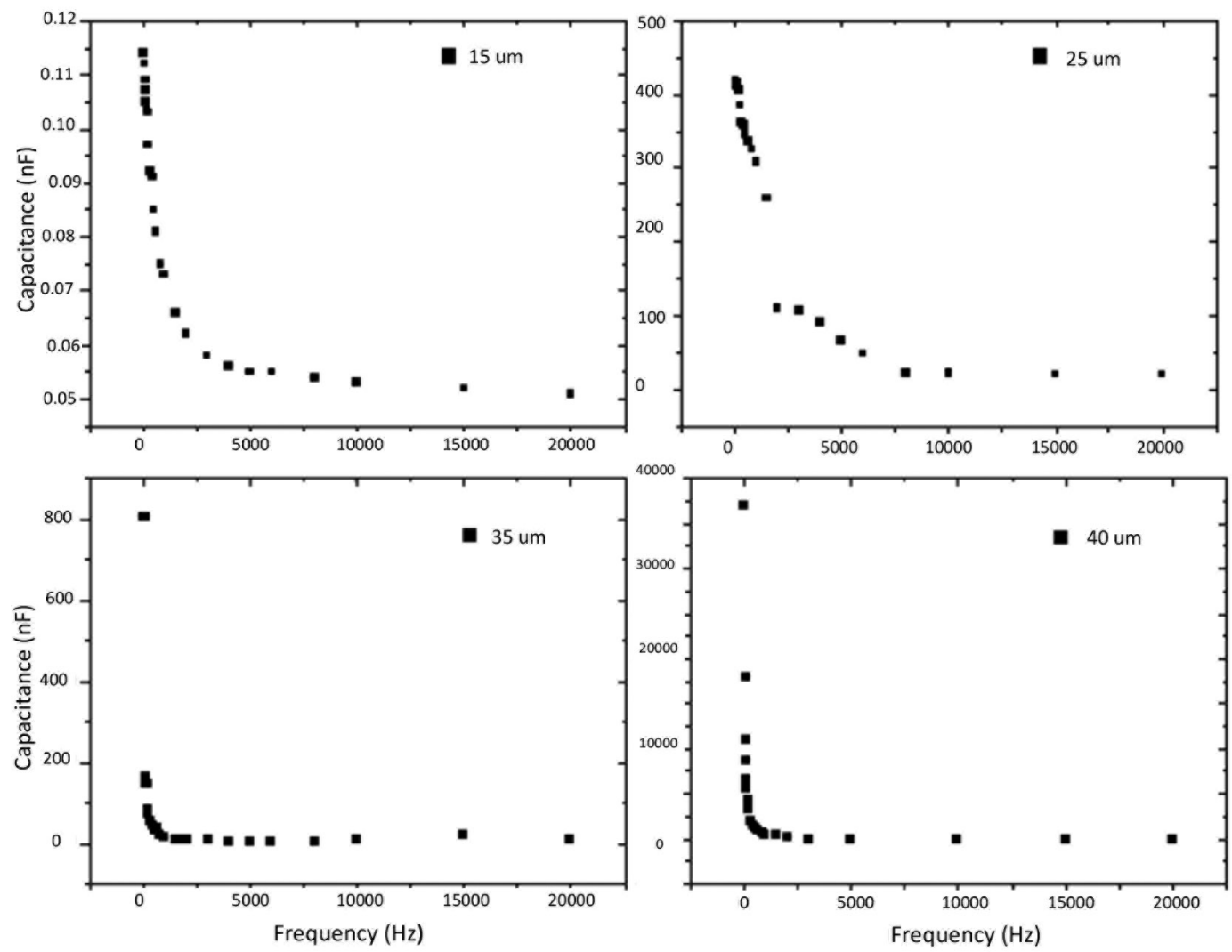

FIGURE 10. Measured capacitance value vs frequency for different diameter of diaphragm

On the other hand, the value of capacitance showed a significant change for each device whereas the value was high for the device with larger diaphragm. Table 3 shows the measured initial capacitance before vibration (C) and after vibration (C) for both from simulated FEA and fabricated device. The results showed the difference between these two values as FEA results represents the behavior of the device based on theoretical model while as for fabricated results be elected by real behavior of the device. This distinction maybe due to the some error from the material or human force during the measurement process.

The capacitance value depends on the separation between the plates. As for microphone, one of the plates is the diaphragm that moves in response to sound, the capacitance value will change as well as the voltage across the plates. The closer the diaphragm with the back plate will gives the higher value of capacitance.

\section{SENSITIVITY}

Figure 11 presents the sensitivity measurement of the proposed graphene based capacitive microphone from FEA analysis. As from the plot, the graphene based capacitive microphone with the largest diaphragm have the highest sensitivity, $-89 \mathrm{~dB}$ compared with the other smaller diaphragms. On the other hand, the smallest diaphragm has the longest flat frequency response.

\section{CONCLUSION}

In summary, this study demonstrated the design, fabrication and characterization of a graphene based capacitive microphone. Using a very thin and durable graphene material as a diaphragm and good transferring process could minimize the defect of the diaphragm and further develop a high performance of microphone. The capacitive measurement is highly related to the theory whereas the

TABLE 3. Summary of the measured initial capacitance, $\mathrm{C}_{\mathrm{o}}$ and final capacitance, $\mathrm{C}$ for FEA and fabricated devices

\begin{tabular}{ccccc}
\hline $\begin{array}{c}\text { Diameter diaphragm } \\
(\mu \mathrm{m})\end{array}$ & $\begin{array}{c}\mathrm{C}_{\mathrm{o}}(\mathrm{FEA}) \\
(\mathrm{pF})\end{array}$ & $\begin{array}{c}\mathrm{C}(\mathrm{FEA}) \\
(\mathrm{pF})\end{array}$ & $\begin{array}{c}\mathrm{C}_{\mathrm{o}}(\exp ) \\
(\mathrm{pF})\end{array}$ & $\begin{array}{c}\mathrm{C}(\exp ) \\
(\mathrm{pF})\end{array}$ \\
\hline 15 & 0.0020 & 0.0025 & 339 & 346 \\
25 & 0.0060 & 0.0067 & 420000 & 420006 \\
35 & 0.0108 & 0.0136 & 804980 & 805005 \\
40 & 0.0162 & 0.0182 & 36999975 & 37000010 \\
\hline
\end{tabular}




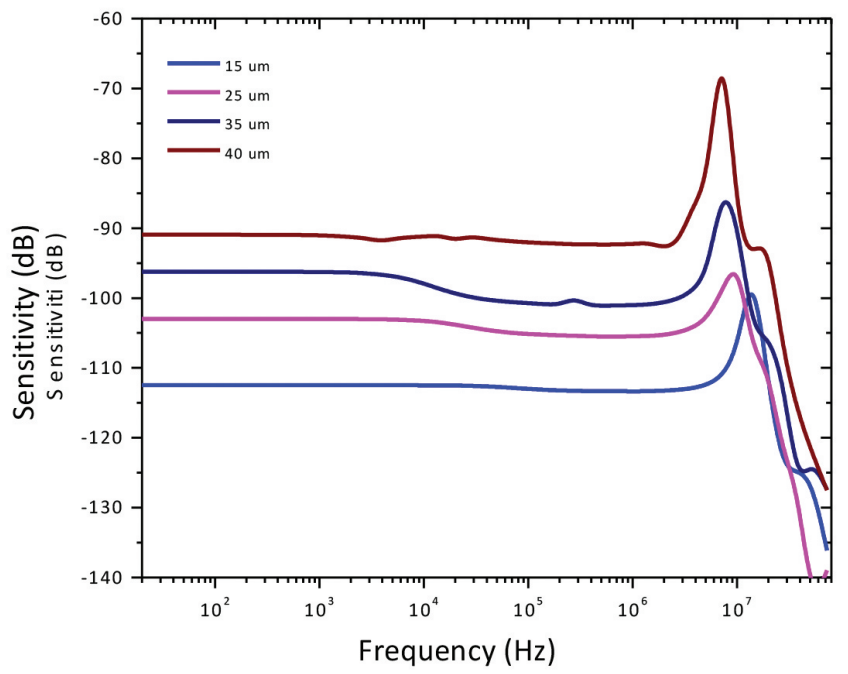

FIGURE 11. Graph of sensitivity $(\mathrm{dB})$ versus frequency response for each diameter diaphragm

capacitance value is directly proportional to the area of the diaphragm. The trend indicated that the value of capacitance decreased when the frequency applied was increased. Beyond this demonstration, we aim to produce the MEMS microphone with a good sensitivity and longer linear response comparable to the existing microphone.

\section{ACKNOWLEDGEMENTS}

This work is supported in part by research grant LRGS/2015/ UKM-UKM/NANOMITE/04/01 from the Ministry of Education Malaysia and grant number GUP-2018-082 from Universiti Kebangsaan Malaysia. H.M.M appreciates the financial aid from MyBRAIN 15, the program from the Ministry of Education Malaysia.

\section{REFERENCES}

Alfons, D. 2007. Silicon microphone development and application. Sensors and Actuators A 133: 283-287.

Berger, C., Phillips, R., Centeno, A., Zurutuza, A. \& Vijayaraghavan, A. 2017. Capacitive pressure sensing with suspended graphene-polymer heterostructure membranes. Nanoscale 9(44): 17439-17449.

Edhuan, I., Mohd Shukri, S., Abd Malek, A.H., Raihan, O., Mohd Asyadi, A.M.A. \& Mohd Hanafi, A. 2017. Synthesis of large-area few-layer graphene by open-flame deposition. Sains Malaysiana 46(7): 1011-1016.

Geim,A.K. \& Novoselov, K.S. 2007. The rise of graphene. Nature Materials 6(3): 183-191.

Hafzaliza, E.Z.A., Azrul Azlan, H. \& Burhanuddin, Y.M. 2017. Characterization of graphene nanolayers grown on MEMS interdigital supercapacitor electrode. Sains Malaysiana 46(7): 1061-1067.

Huang, H., Chen, S., Wee, A.T.S. \& Chen, W. 2014. Epitaxial growth of graphene on silicon carbide (SiC). In Graphene Properties, Preparation, Characterisation and Devices, edited by Skákalová, V. \& Kaiser,A.B. Cambridge: Woodhead Publishing. pp. 3-26. 10.1533/9780857099334.1.3.
Md. Sajibul, A.B., Md. Nizam, U., Md. Maksudul, I., Ferdaushi, A.B. \& Sayed Shafayat, H. 2016. Synthesis of graphene. International Nano Letters 6(2): 65-83.

Pedersen, M., Olthuis, W. \& Bergveld, P. 1997. A silicon condenser microphone with polyimide diaphragm and backplate. Sensors and Actuators A: Physical 63(2): 97-104

Todorovic, D., Matkovic, A., Milicevic, M., Jovanovic, D., Gajic, R., Salom, I. \& Spasenovic, M. 2015. Multilayer graphene condenser microphone. 2D Materials 2(4): 045013.

Wang, W.J., Lin, R.M., Zou, Q.B. \& Li, X.X. 2004. Modeling and characterization of a silicon condenser microphone. $J$. Micromech. Microeng. 14: 403-409.

Wang, D., Fan, S. \& Jin, W. 2015. Graphene diaphragm analysis for pressure acoustic sensor applications. Microsyst. Technology 21: 117-122.

Zhou, Q. \& Zettl, A. 2013. Electrostatic graphene loudspeaker. Applied Physics Letter 102: 109-223.

Zhou, Q., Zhen, J., Onishi, S., Crommie, M.F. \& Zettl,A.K. 2015. Graphene electrostatic microphone and ultrasonic radio. Science PNAS 112: 8942-8946.

Haslinawati Mohd Mustapha, M.F. Mohd Razip Wee, Ahmad Rifqi Md Zain \& Mohd Ambri Mohamed* Institute of Microengineering and Nanoelectronic

Universiti Kebangsaan Malaysia 43600 UKM Bangi, Selangor Darul Ehsan Malaysia

Ahmad Rifqi Md Zain

Harvard John A Paulson

School of Engineering and Applied Science

Harvard University, Cambridge, MA

United States of America

*Corresponding author; email: ambri@ukm.edu.my

Received: 25 August 2018

Accepted: 15 January 2019 